\title{
The Händelö area in Norrköping, Sweden Does it fit for Industrial Symbiosis development?
}

\author{
Saeid Hatefipour ${ }^{1, *}$, Leenard Baas ${ }^{1}$, Mats Eklund ${ }^{1}$ \\ ${ }^{1}$ Division of Environmental Technology \& Management - Department of Management \& Engineering, \\ Linköping University, Linköping, Sweden \\ ${ }^{*}$ Corresponding author. Tel: +46 (0) 132856 27, E-mail: saeid.hatefipour@liu.se
}

\begin{abstract}
Today, sustainable cities/regions are playing an important role in sustainable development projects. The overall aim of the current paper is to demonstrate an Industrial Symbiosis development in the Händelö area of Norrköping city in the Östergötland county of Sweden. It is part of a research program called "Sustainable Norrköping” focusing on developing links between the industrial and the urban part of the city. As analysis of the current situation is important for understanding the future development, the paper tries to map the current industrial symbiosis links and symbiotic network to identify potentials exist. To achieve this, paper gives a general view of how this area has been developed, constructed, and grown. The next stage is devoted to an inventory of different actors, stakeholders, and companies, their processes and relationships in the form of energy, materials and by-products exchanges, flows and streams into and out of the Händelö area considering the Händelö/Norrköping as system boundaries. In addition, by describing different tools, elements and approaches of industrial symbiosis and considering and applying two main key tools as industrial inventories and input/output matching the paper also tries to show that whether the already industrial activities formed inside the Händelö fits for an industrial symbiosis development.
\end{abstract}

Keywords: Sustainable Regions, Norrköping, Händelö Area, Industrial Symbiosis (IS)

\section{Introduction}

Eco-industrial and sustainable regional/industrial developments are terms that now a days researchers, regional planners and business developers are encountered with. During the recent years, a substantial amount of research works has been conducted through emerging field of industrial ecology and one of its major applicable parts, industrial symbiosis. Almost both fields' aims are addressing sustainable development through systems at different levels and approaches. Hence, industrial symbiosis has been suggested as an efficient and applicable tool for sustainable regional/industrial development. Going back to historical view of industrial ecology, Erkman [1] proposed an analogy between industrial systems and natural ecosystems in which industrial systems and its processes are explained as mimicking the nature. The main elements of an industrial system are introduced as energy, materials, and information that flow inside the system. Chertow defined that industrial ecology preforms at three levels; "facility or firm", "inter-firm", and "regional/global" level. Moreover, as industrial symbiosis involves exchange cases amongst several firms, hence industrial symbiosis operates at "inter-firm" level. In a system perspective, by definitions, Chertow has defined key elements to IS as, "the keys to IS are collaboration and the synergistic possibilities offered by geographic proximity" and "Industrial symbiosis engages traditionally separate industries in a collective approach to competitive advantage involving physical exchange of materials, energy, water, and/or by-products” [2]. Ristola \& Mirata enhanced the sustainability of localized industrial systems using industrial symbiosis. Moreover, regional scale of industrial symbiosis is currently applied worldwide as a tool with the aim of developing more sustainable regions [3]. In a Swedish case study of the Landskrona industrial symbiosis project, the industrial symbiosis networks and its contribution to regional environmental innovation has been investigated by Mirata \& Emtairah [4]. 
The present study is somehow intertwined with two current research projects at the division of environmental technology and management at Linköping University. From one side, it is part of a research program called "Sustainable Norrköping" which tries to study links between the industrial and urban part of the city. On the other side, it can be part of the Industrial Ecology Research Program (IERP), a research program developed in the framework of a 10-year funding agreement between TEKNISKA VERKEN (the energy corporation in Linköping) and Linköping University. IERP mainly focuses on regional Industrial Symbiosis development in Östergötland county of Sweden. It will show how and whether industrial symbiosis has the potential and capability to be an applicable tool towards regional sustainable development. Furthermore, it will practice how industrial symbiosis can contribute to a sustainable Östergötland development network. However, the Händelö area project is a real case as a sublocal development that can be expanded to a local (Norrköping city) and regional (Östergötland county) development. Hence, the current paper tries to find how industrial symbiosis fits in industrial activities of Händelö area at city of Norrköping. In the next phase, we analyze material exchange types at a spatial/organizational scale of Industrial Symbiosis by the application of a geographic information system (GIS) tool. Moreover, concepts like contribution to a $\mathrm{CO}_{2}$-neutral eco-industrial park, moving toward maximize sharing of renewable energy resources will be also investigated in the next development stages of our research.

\section{Methodology}

The paper is being formulated based on the following approaches. First of all, a literature review with the subject of industrial ecology/industrial symbiosis projects and regional sustainable development has been performed, aiming at recognizing the main characteristics, challenges, and opportunities that other industrial symbiosis projects and regional development cases were encountered with. In the next stage, an inventory of the actors or an industrial inventory as one of the useful industrial symbiosis tools is introduced [2]. In this regard, an inventory of participating actors along with their processes is provided and analyzed. These types of information are mainly collected from interviews with key actors, field visits, and by setting up a technical meeting with responsible organizations involved in a regional project. Using a case study is another methodology used in this paper. As there are several actors in the city of Norrköping and the city consists of different parts and areas that have some technical, business and social relation with each other, the focus in this paper is mainly devoted to Händelö area and the energy cluster at Händelö as the nominated area for industrial symbiosis.

\section{Results}

\subsection{Lessons learned from industrial symbiosis concepts and applications}

Being deeper in most of recent and current industrial symbiosis or eco-industrial park projects worldwide, it is evident that there are some key items, concepts, approaches, tools and elements which have been used, discussed, and applied during those projects. Amongst several industrial symbiosis projects world wide, the Kalundborg in Denmark was pioneer in experiencing an industrial symbiosis model to create an eco-industrial park [2]. In this regard, it is shown that the Kalundborg's achievements not only energy, water, and waste exchanges, which have lead to better environmental and economic performances, but also social-human dimensions, equipment and information sharing were involved as well. On the basis of literature and projects experiencing in the field of industrial symbiosis [2,5], approaches, measures, key items, elements, applicable tools and definitions of different aspects of industrial symbiosis and industrial symbiosis projects have been found. With this knowledge in the first round of research can be identified whether an industrial area and the participants 
in the symbiosis can be matched with industrial symbiosis or not. Those elements and key items are summarized below.

\subsubsection{Industrial Symbiosis tools}

Regarding industrial symbiosis tools, Chertow [5] has defined several useful tools in industrial symbiosis analysis like industrial inventories, input/output matching, stakeholder processes, and material budgeting. It is suggested that, as soon as an industrial area is considered of interest for industrial symbiosis, the first step through an industrial symbiosis analysis can start with an inventory of local actors and relevant organizations. In the same literature, input/output matching has been introduced as "key to symbioses" for links of companies. Three methods: written surveys, interviews and utilizing simulation softwares, are mentioned for data gathering and analysis. Another industrial symbiosis tool is defined as materials budgeting, in which the aim is to map the energy and material flows through an industrial system. As the tool can help to map the route of flows and stocks, it could be fundamental to an industrial symbiosis analysis. Moreover, it is defined that, "The material budgeting can be a basic building block of an industrial symbiosis analysis” [5].

\subsubsection{Elements of Industrial Symbiosis}

Items such as embedded energy and materials, life cycle perspective, cascading, loop closing, and tracking material flows have been introduced by Chertow as elements of industrial symbiosis [5]. Embedded energy and materials is an industrial symbiosis element which shows that the sum of materials and energy consumed to generate a new product is equal to the amount of embedded in that product. Hence, "reusing by-products" in industrial symbiosis links, maintains the embedded materials and energy for a longer time within the industrial systems. Environmental impacts which appear at every stage of product life cycles, considered as life cycle perspective. According to industrial symbiosis, life cycle perspective is used to evaluating symbiotic opportunities. When energy or water recourses are consumed many times in several different relevancies, cascading is appeared. Cascading has been defined as a prevalent policy for industrial symbiosis; hence the environmental advantages of cascading are several. A special type of cascading is loop closing, where it is considered more ring-shaped. The environmental and economic advantages of loop closing are alike to those in cascading. Tracking of energy, water and material flows has been defined as another key to industrial symbiosis analysis. It is shown that applying material tracking at different levels has contributed to definite industrial ecology tools: substance flow analysis (SFA) and material flow analysis (MFA).

\subsubsection{Material exchange types versus Spatial/organizational scale of industrial symbiosis}

As different exchanges has different proximity and the distance amongst partners and organizations in industrial symbiosis plays an important role, hence another aspect of industrial symbiosis is devoted to the spatial scale of industrial symbiosis. The geographic proximity amongst firms refers directly to the spatial scale. In this regard Chertow proposed a methodology based on taxonomy of 5 different material exchange types to consider both components, spatial scale and materials exchange [2,5].

Type 1: through waste exchanges

Type 2: within a facility, firm, or organization

Type 3: among firms co-located in a defined Eco-Industrial Park

Type 4: among local firms that are not co-located

Type 5: among firms organized virtually across a broader region 
In addition, Chertow argued a "3-2 heuristic" definition in which at least three different actors exchanging at least two distinct material/resources; differentiating industrial symbiosis from linear one-way exchanges [6]. More than that, it is discussed that types 3-5 "can readily be identified as industrial symbiosis" [2].

\subsubsection{Exchange types and synergistic possibilities}

The most common type of exchanges are considered as resource exchanges in which energy, raw material, waste handling, and by-products are cycling amongst different actors and firms based on a predefined collaboration. Considering several literature and researches [2,5], the concepts such as synergies and synergistic possibilities are argued. "Synergistic possibilities offered by geographic proximity" has been defined as key to industrial symbiosis. Synergistic possibilities may refer to both material exchanges and by-product exchanges. Chertow showed that by-product exchanges can be transported in a longer distances while the material exchanges (steam, hot water...), cannot be economically applied in longer distances and crossing the boundaries of symbiotic network [2]. In this regard, in the case of collaboration between different firms, industries and organizations, the synergistic possibilities may refer to business and economic synergies as well. A classification of different exchanges in the form of synergies amongst firms and industries has been defined by the Center of Excellence in Cleaner Production (CECP) [7]. They categorized the exchanges as supply, by-product, and utility synergies.

\subsubsection{Industrial symbiosis project development}

Chertow [2] discussed several examples of industrial symbiosis projects along with ecoindustrial park projects in which different definitions regarding to project development, types of industrial symbiosis networks, and planning stages are being defined. In this regard, the symbioses can be developed based on a planned and structured process in contrast with continually spontaneously evolved projects in which several firms and partners in the symbiosis have developed and evolved simultaneously over time. Furthermore, the participants in industrial symbiosis can be defined as conscious or unconscious network regarding to the environmental characteristics of their exchanges. According to planning stages and development progress of industrial symbiosis projects, a sampling of twelve industrial symbiosis projects reviewed by Chertow [2], shows that most of the industrial symbiosis projects can be categorized in the phases: late planning, implementation phase, operational stages, and project completed. In addition, in the case of a planned project, different approaches are applicable. A project could be considered and performed as "StreamBased" or "Business-Based". Similarly, an eco-Industrial park as a planned project would begin based on "New or Existing Operations". As an example it is implied that the case of the industrial district in Kalundborg Denmark, was a continually spontaneously developed project in which different partnerships in the symbiosis have evolved during the years. More than that, it is concluded that the spontaneous projects in contrast with planned and structured ecoindustrial parks, "are proving to be more robust and resilient to market dynamics", [5].

\subsection{History and background of the Händelö area}

Händelö is a 600-hectare island in the Baltic Sea, just outside the city of Norrköping in the county of Östergötland in Sweden. The Händelö Island is surrounded by Motala River and Bråviken Bay. Historically, Händelö farm has registered on 1322, 60 years before Norrköping became a city. Vast areas of the former farm have been built by industries during the recent years. Now, over the years, the farm itself may be developed into a center of environmental technology, which owned green companies and clean technologies to generate sustainable economy. Due to the nature of Händelö, the area is also called as coexistence between 
conservation of nature and industrial sites both locates on an island with high business and economy potentials as well as high nature value, which makes the Händelö area being as a meeting point for nature and technology in a sustainable way. For around three decades, it is planned for large and new establishment of industries and infrastructure. Norrköping municipality owns Händelö area. Nowadays, the Händelö Island has vast and distinct facilities inside. Because of that it attracted the interests of business planners/developers, local authorities, and academia researchers. Facilities like the center of logistics companies, the renewable energy cluster and Natura 2000 conservation areas. More than that, the strategic position of the area such as access to the railway and vicinity to the harbor is another order of merits of the Händelö area.

\subsection{An overview of an industrial ecosystem in Norrköping, Sweden}

The current paper is a case study to examine industrial symbiosis in a sustainable development application at Händelö area in Norrköping. Nevertheless, for deeper understanding and further realization of relations between different parties inside and outside the border of Händelö, a brief description about the current situation of industrial ecosystem at Norrköping is given. Figure 1 shows a schematic relation and collaboration between different actors and organizations in Norrköping. The involved exchanges include mainly energy, materials/waste, and by-products. Municipal wastes from Norrköping city feed into E.ON, the combined heat and power plant that produces heat, electricity, and process steam. Heat is delivered to the district heating network, electricity to the grid, and steam to the nearby ethanol production plant (Agroetanol). Wheat from the agriculture sector feeds to the Agroetanol Company, which produces pure ethanol. The produced ethanol is used as vehicle fuel. Stillage, a by-product from the ethanol plant, is delivered to a biogas production plant, Svensk Biogas to produce vehicle biogas and bio-fertilizer for the agriculture sector.

Econova is an enterprise in the environmental technology sector and its main activities focus on products and services in the field of biomass, landfills, waste \& by-products, and gardening. In this regard, Econova basically runs on two distinct business areas called Econova Energy and Econova Garden. The first one's activities are utilizing and processing waste and by-products from municipalities and the forest industry. The second one's activities are based on producing and selling environmentally friendly garden products. Hence, the company's main strategies are based on "eco-cycle" thinking and effective use of resources in an environmentally and economically efficient way. The business strategies of Econova facilitate that more and more customers organize their activities in local cycles. Furthermore, those strategies contribute to more efficient environment, better social relationships along with increasing resources economy. The main business partners of Econova are the agriculture sector, who receives bio-fertilizer, the forest sector which exchange biomass and bio ashes, the waste water treatment plant for sludge exchange, the municipalities for organic and household waste, and the CHP plant for exchanges of ashes and biomass [8].

Returpack and Cleanaway are neighbor companies with an unique strategy in closed ecocycle system for depositing, handling, collecting, recycling of pet bottles and aluminum cans at Händelö in Norrköping. Returpack is the company in charge of the Swedish pet bottles and aluminum cans deposit system since 2003. They selected Norrköping for its vast facilities in logistics. Around 20,000 tonnes per year of pet bottles are delivered to Returpack. The daily processing is about 3.6 million Aluminum cans and pet (9). The transportation costs for sending this amount of pet bottles and Aluminum cans for recycling to other regions were too high so it was decided to follow the "Next door" strategy to build the Cleanaway Company close to Returpack to avoid logistic/transportation costs. Cleanaway, business partner of 
Returpack is a company in charge of cleaning and recycling of pet bottles, and is constructed in 2006. Cleanaway delivered about 8 tonnes per day of pet bottles and around 27,000 of pet bottles per annual of which 20,000 tonnes brought in from Returpack and rest comes from Norway and Finland [9]. Around 75\% of cleaned pet materials are used for producing new pet bottles, and the rest is used for producing other plastic products. The process waste is sent to the E.ON CHP plant at Händelö as combustible materials. The key successive items through collaboration between Cleanaway and Returpack is the "wall to wall" strategy which contribute to a set-up based on an agreement "among firms collocated in a defined ecoindustrial perk".

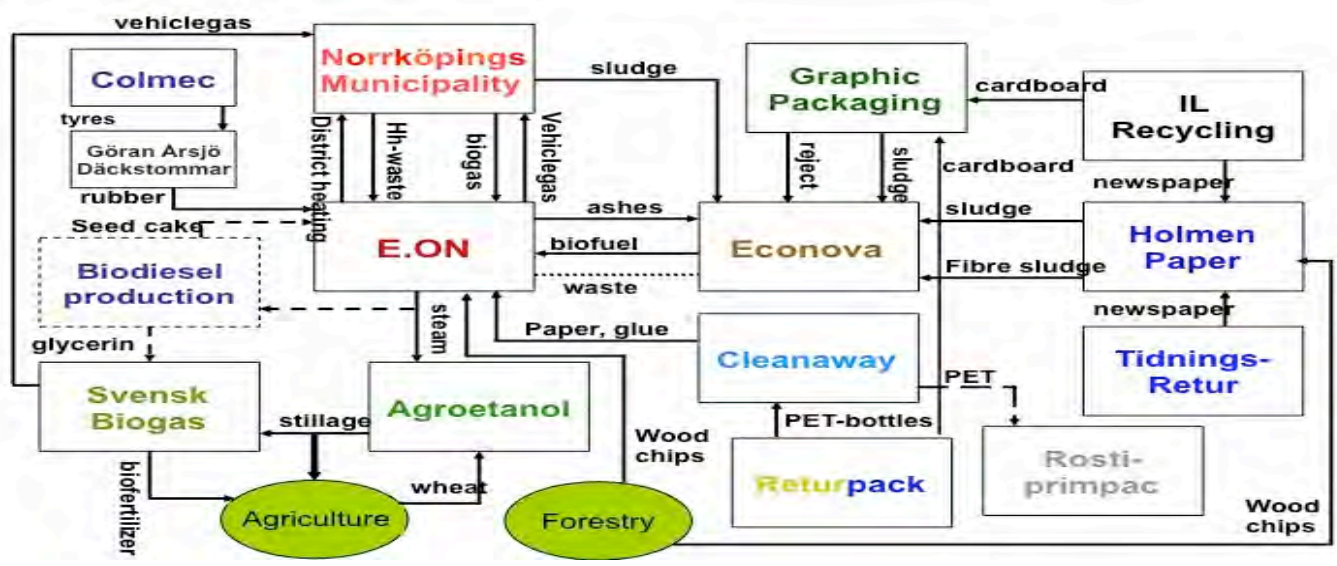

Fig. 1. Industrial eco-system at city of Norrköping (10)

\subsection{Industrial symbiosis tools applicable at Händelö}

As stated, an industrial inventory (inventory of the actors) is introduced as one of the useful industrial symbiosis tools. As soon as an industrial area is nominated as a possibility for industrial symbiosis, the first step through an industrial symbiosis analysis could be starting with an inventory of local actors and relevant organizations. Another industrial symbiosis tool is defined as materials budgeting, in which the aim is to map the energy and material flows through the nominated area. As the tool can help to map the route of flows and stocks, it could be fundamental to an industrial symbiosis analysis [5].

The energy services company, bio fuel (biogas, bioethanol) production companies, the agriculture sector, forestry, logistic companies, pet bottles, aluminum cans, and rubber tires recycling companies are major green partners through their links and the applications of clean technologies. Händelö became the center of industrial symbiosis and environmental technology to stimulate a sustainable economy in the area. As there are several actors and industrial companies in different sectors at Händelö that share some technical, business and social relationships with each other, the focus in this paper is mainly on the Händelö area and the energy cluster as the nominated area for industrial symbiosis. In this regard, an inventory of participating companies in the area and their processes containing energy, material, waste, and by-products exchanges along with mapping the energy and material flows through the area is provided and analyzed.

\subsubsection{Industrial inventory at Händelö energy cluster}

As discussed earlier, the energy cluster at Händelö area is part of the eco-industrial complex in Norrköping city. The primary partners at Händelö energy cluster are E.ON CHP plant, Lantmännen Agroetanol (ethanol production company), and Svensk Biogas (bio-gas production company) [9]. 
The E.ON combined heat and power plant as the engine, is a part of energy cluster at Händelö. E.ON produces heat and electricity that is delivered to the municipality of Norrköping. In addition E.ON produces process steam for the nearby ethanol production plant (Lantmännen Agroetanol). The municipality of Norrköping provides household waste to E.ON to use in their waste incineration plant. The main fuels to E.ON are wood/return chips, wood waste, rubber tires, and sorted household waste. The fuels contain $53 \%$ of biomass, $43 \%$ waste, $4 \%$ coal, and small amounts of oil during peak loads. The waste consumption of the incineration plant is about 20 tones per hour at full power. The overall heat capacity of the plant is around 1.1TWh including steam. The power production of the unit reaches to $300 \mathrm{GWh}$. Of the total energy produced, $57 \%$ is processed into heat and is delivered to the district-heating network, $29 \%$ is processed into steam, which is delivered to the ethanol production plant, and $14 \%$ is processed into electricity that is delivered to the grid. Lantmännen Agroetanol is Sweden's only large-scale producer of grain-based fuel ethanol and has a large production plant at Händelö. Due to high demand for ethanol as a fuel in Sweden, it has expanded its production plant in Norrköping. The plant is also one of the Sweden's largest producers of protein-rich crops and feedstuff for animal feeding. At the Norrköping plant, wheat is the main raw material. The first batch of ethanol was delivered from the plant in 2001. In November 2008 the second production line started. This yields to an expansion in capacity to produce 210 million liters of bio-ethanol and 195 thousands tones of protein feed (DDGS) annually. The production is based on 550,000 tones of cereals. Lantmännen Agroetanol has several industrial, commercial, and social links with other companies in and outside the Norrköping region. E.ON, Svensk Biogas, oil companies, farmers, and animal feed factories are the main Lantmännen Agroetanol counterparts.

Svensk Biogas (Swedish Biogas) at Händelö has started in 2007. Biogas is produced from organic waste and residues. Sewage sludge, stillage, grains, crops, and plants from the agriculture sector are the most frequently used raw materials for biogas production plant at Händelö. Stillage is provided from the nearby ethanol production company and sewage sludge is a by-product of the wastewater treatment plant. Amongst different by-products of the biogas plant, the most important ones are bio-fertilizer and bio-manure which both return to the agriculture sector again. The produced biogas is refined and is fed into city gas filling stations for both private and public transportation. The biogas plant at Händelö produces around 2.6 million $\mathrm{Nm}^{3}$ /year biogas.

\section{Discussion and Conclusions}

Having a look upon the business partners, actors and their processes at Händelö, it is evident that the most common type of material exchanges through the symbiotic network is a combination of both types tree and four, in which the exchanges are mainly, occurs "among firms co-located" in a symbiotic network. Stillage the by-product of the ethanol company is feed to both biogas plants at Händelö in its geographic proximity as well as to a more distant plant in Linköping, "over the fence”. As the primary partners are linked together within a fewmile vicinity and have advantages of exchanging energy and materials, it can be classified as a type four exchange. As spatial/organizational scale of industrial symbiosis plays an important role in issues like material exchange types and geographic proximity amongst actors, the "Geographic Information System (GIS) tool" can be added as a new component to industrial symbiosis analysis. Considering two definitions of eco-industrial parks by USA/EPA and President's Council on Sustainable Developments (PCSD) [2], the Händelö area can be classified and evaluated as an eco-industrial park. Based on further steps in the research and its analysis, new definitions like $\mathrm{CO}_{2}$-neutral eco-industrial parks through maximize sharing of renewables energy resources can be found. 
Performing an industrial inventory as a starting point through an industrial symbiosis analysis shows how local actors depend on each other through the entire network. In this regard, Händelö is a clear sample of "cooperation between different industries by which the presence of each increases the viability of the others, and by which the demands of society for resource savings and environmental protection are considered" [2]. Having a look from an industrial symbiosis perspective at Händelö, it is easily seen that collaboration and synergistic possibilities within a geographic proximity are entirely embedded through the area. More than that, reusing by-products is a dominant process through the whole network where embedded energy and materials links as an industrial symbiosis tool is already performed. In addition the synergistic possibilities and exchanges are mainly devoted to by-product synergies and utility synergies. It is evident that the participants in the Händelö energy cluster have generated a conscious network with regard to the environmental characteristics of their exchanges. More than that it seems that the Händelö symbiotic network and the symbiosis is a type of continually spontaneously evolving projects in which several new firms and partners in the symbiosis have developed and evolved simultaneously over time. Rather than that, the Händelö energy cluster seems to be a sample of an "integrated bio-system" in which the involved processes mainly come from industry and agriculture [2]. Finally, an overview of industrial activities in both local (Norrköping city) and sub-local (Händelö area) level and specifically the energy cluster at Händelö shows social-human dimension of industrial symbiosis such as trust and communications are the most key factors in cooperation between the participants at the Händelö symbiotic network. In addition, amongst several current samples of industrial symbiosis projects and eco-industrial parks worldwide, the keyword industrial symbiosis, can be coined to green economies and clean technologies that have already formed at Händelö.

\section{References}

[1] Erkman S., Industrial ecology: an historical view, J. of Cleaner Prod. Vol.5, pp. 1-10

[2] Chertow, M., Industrial Symbiosis: Literature and Taxonomy. Annual review of energy and environment, 25, 313-337

[3] Ristola P., Mirata, M., Industrial symbiosis for more sustainable, localized industrial systems, Progress in Industrial Ecology- An International Journal, Vol. 4, Nos. 3/4, pp.184-204

[4] Mirata M., Emtairah T., Industrial symbiosis networks and the contribution to environmental innovation: the case of the Landskrona industrial symbiosis program, Journal of Cleaner Production 13 (10-11), 993 - 1002

[5] Chertow, M., Lifset, R.,Industrial symbiosis,www.eoearth.org/article/industrial_symbiosis

[6] Chertow, M. “'Uncovering’ Industrial Symbiosis.” J. of Industrial Ecology, 11(1): 11-30

[7] Center of Excellence in Cleaner Production (CECP), Regional resources synergies for sustainable development in heavy industrial areas: An overview of opportunities and experiences, Perth, Australia, Curtin University of Technology, 2007

[8] Econova AB (2010). Econova AB Homepage. 2010, www.econova.se

[9] Cleantech Östergötland (2009), the energy complex at Händelö. Cleantech magazineenvironmental technology in the twin cities of Sweden, 1, pp.16-17

[10] Nicklasson, D., Industrial ecology for development and marketing of trade and industry in Norrköping, Master thesis, LIU-IEI-TEK-A--07/00259—SE 